\title{
Basophils response to Pru p 3 and Ara h 9 in patients sensitised to peach under specific immunotherapy
}

\author{
Francisca Gomez ${ }^{1 *}$, Enrique Gomez 2 , Inmaculada Doña ${ }^{3}$, Luisa Galindo ${ }^{3}$, Paloma Campo ${ }^{3}$, Teresa Posadas ${ }^{3}$,
}

Maria Jose Torres ${ }^{3}$, Araceli Diaz-Perales ${ }^{4}$, Miguel Blanca ${ }^{3}$, Lina Mayorga ${ }^{2}$

From 5th International Symposium on Molecular Allergology (ISMA 2013)

Vienna, Austria. 6-7 December 2013

\section{Rationale}

In Southern Europe Pru p3 is the primary sensitizer of plants fruit and it is responsible of severe reactions. Specific immunotherapy (SIT) brings a new perspective to treat those patients. There is a lack of knowledge regarding cellular responses that include changes in the basophil activation during the IT. We aim to analyse early changes in the basophil response to Pru p 3 and other related allergen (Ara h 9) after the first month of sublingual immunotherapy (SLIT).

\section{Methods}

Forty-six peach allergic patients confirmed by positive specific IgE determined by skin prick test or fresh peach (prick-by-prick), ImmunoCAP IgE and/or a double blind placebo control food challenge with peach. Basophil reactivity was determined by the basophil activation test (BAT) with Pru p 3 and Ara h 9 at two concentrations, 1 and $0.1 \mu \mathrm{g} / \mathrm{ml}$, before and after $1 \mathrm{month}$ of SLIT.

\section{Results}

Twenty one patients evaluated (45\%) performed anaphylaxis and 25 (55\%) urticaria and/or angioedema. The $82,6 \%$ showed sensitization to other plant foods proteins and $69,5 \%$ showed sensitization to pollens. The BAT was done in 25 patients with first month of SLIT completed. The $28 \%$ patients have an increase of Pru p 3 reactivity. The $36 \%$ patients showed same reactivity after first month and $36 \%$ presented a decreased reactivity to Pru p3. Similar results were obtained for Ara h 9 in those patients.

${ }^{1}$ Hospital Carlos Haya, Malaga, C/Canillas de Aceituno No 5 Portal $24^{\circ} \mathrm{D}$ Málaga, 29004, Spain

Full list of author information is available at the end of the article

\section{Conclusion}

Preliminary result disclosed that percentage of patients who underwent changes in BAT reactivity to Pru p3 and Ara $\mathrm{h} 9$ was similar. There have been no differential clinical pattern in the groups studied after one month of SLIT. The BAT shows a good correlation between both Pru p 3 and Ara h 9.

\section{Authors' details \\ ${ }^{1}$ Hospital Carlos Haya, Malaga, C/Canillas de Aceituno № 5 Portal $24^{\circ} \mathrm{D}$, Málaga, 29004, Spain. ${ }^{2}$ Research Laboratory, Carlos Haya Hospital-FIMABIS, Málaga, Spain. ${ }^{3}$ Allergy Service, Carlos Haya Hospital, Málaga, Spain. ${ }^{4}$ Plant Biotechnology Institute (UPM-INIA), Madrid, Spain.}

Published: 17 March 2014

doi:10.1186/2045-7022-4-S2-019

Cite this article as: Gomez et al: Basophils response to Pru p 3 and Ara h 9 in patients sensitised to peach under specific immunotherapy. Clinical and Translational Allergy 2014 4(Suppl 2):O19.

Submit your next manuscript to BioMed Central and take full advantage of:

- Convenient online submission

- Thorough peer review

- No space constraints or color figure charges

- Immediate publication on acceptance

- Inclusion in PubMed, CAS, Scopus and Google Scholar

- Research which is freely available for redistribution

Submit your manuscript at www.biomedcentral.com/submit
() Biomed Central 